\title{
KATEGORIA OBECNOŚCI W KONTEKŚCIE RELIGII
}

\section{WIELOZNACZNOŚĆ KATEGORII OBECNOŚCI}

W historii filozofii dyskusja nad kategorią obecności podejmowana była stosunkowo rzadko. Dopiero XX-wieczne szkoły filozoficzne, takie jak fenomenologia, egzystencjalizm czy nurt personalistyczny, nadały pojęciu obecności znaczącą pozycję w naukowej refleksji. Kategoria obecności ma charakter wieloznaczny, stosowanie jej w różnych dyskursach filozoficznych i pokrewnych wymaga zatem każdorazowo rozjaśnienia i dookreślenia ${ }^{1}$. Na kwestię tę zwraca uwagę m.in. Barbara Skarga, pisząc o swoistym rozcięciu pomiędzy różnymi sposobami mówienia o obecności, wskazując na ontologię, teorię poznania i antropologię. Skarga pisze tak oto:

Wpierw więc pojawia się rozcięcie między tym, co epistemologiczne i ontologiczne, rozcięcie związane także z ujęciem czasowości. W etapie drugim reinterpretacja obecności ujawnia swój związek z podmiotowością. I właśnie w tym momencie ujawniają się także dwie drogi, radykalna krytyka obecności lub, przeciwnie, jej pogłębiona antropologizacja i umetafizycznienie ${ }^{2}$.

1 Por. S. Gałkowski, „Homo est” $i$ „Ecce homo”. Kategoria obecności w filozofii klasycznej, [w:] Metafizyka obecności, red. A. Bobko, M. Kozak, Kraków 20o6, s. 19.

${ }^{2}$ B. Skarga, Ślad i obecność, Warszawa 2002, s. 36. 
W dyskursie o obecności stosuje się również inne rozróżnienia. Po pierwsze, wskazuje się na obecność absolutną, niezależną od podmiotu uchwytującego ową obecność, np. obecność ciał w przestrzeni fizycznej. Po drugie, można mówić o obecności jako byciu dla kogoś lub czegoś. W tym ujęciu obecność pojmowana jest najogólniej jako „[...] pierwotne, nieprzesycone żadną treścią zetknięcie się z rzeczywistością"”. Jest to zatem ustosunkowanie świadomości wobec innego bytu, otwierające możliwość poznania i oddziaływania, a w określonych przypadkach możliwość spotkania i dialogu. Wieloznaczność pojęcia obecności jest szczególnie widoczna w jego ujęciu leksykalnym. Słowo obecności związane jest z greckim terminem parousi, który łączy się z kolei z czasownikiem pareimi, który oznacza: „być przy”, „być podczas”, „być w”, „być obecnym”, „być blisko”, „być obok”, „stać przy”, „stać obok”, jak również "nadejść", „przyjść". Według Stownika języka polskiego „obecny” oznacza będący „wobec”, np.: wobec sądu, wobec drugiego człowieka, wobec Boga. „Bycie wobec” oznacza obcowanie z czymś, co pomimo swojej obcości bycia niejako na zewnątrz świadomości uchwytującej obecność, może stać się jej bliskie ${ }^{5}$.

\section{OBECNOŚĆ JAKO BYCIE DLA}

Zgodnie z Husserlowskim paradygmatem obecność jest zawsze obecnością dla kogoś, byciem dla świadomości ${ }^{6}$, jest też obecnością przedmiotu jako korelatu intencjonalnego aktu spostrzegania ${ }^{7}$. Martin Heidegger z kolei podkreśla, iż obecność jest sposobem bycia Dasein, jego wspótbyciem jako warunkiem rozumienia, mającego charakter projektujący ${ }^{8}$.

3 S. Gałkowski, „Homo est” $i$ „Ecce homo”..., dz. cyt., s. 19-2o.

${ }^{4}$ Por. S. T. Kołodziejczyk, Nieobecność jako kategoria metafizyczna i epistemologiczna, [w:] Metafizyka obecności..., dz. cyt., s. 32.

${ }^{5}$ Por. B. Skarga, Ślad..., dz. cyt., s. 33-40.

${ }^{6}$ Por. B. Skarga, Ślad..., dz. cyt., s. 45.

7 Por. B. Skarga, Ślad..., dz. cyt., s. 38

8 Por. B. Skarga, Ślad..., dz. cyt., s. 40. 
Pierwsze ujęcie obecności ma zatem charakter epistemologiczny, drugie egzystencjalny, obydwa zaś wiążą wyraźnie obecność z tym, co podmiotowe. Z uwagi na cel niniejszej pracy przyjrzymy się teraz z większą uwagą kategorii obecności, właśnie w kontekście tego, co podmiotowe i międzyosobowe. Już na wstępie należy zaznaczyć doniosły fakt, iż obecność człowieka dla drugiego człowieka wiąże się z kluczową rolą świadka. Funkcja przyświadczenia jest w tym wypadku nie tylko prostym stwierdzeniem faktu istnienia tego, któremu przyświadczamy, lecz również - a może przede wszystkim - pogłębionym, zaangażowanym ustosunkowaniem do rzeczywistości drugiej osoby, zdolnością do przyjęcia afirmatywnej postawy wobec niej, niejako stworzeniem warunków możliwości jej uobecnienia: świadek kontempluje tego, komu przyświadcza9 . W tym też sensie można mówić o obecności jako byciu dla. Obecność w horyzoncie tego, co podmiotowe: „[... ] jest zawsze współobecnością”" Istnieje zasadnicza różnica między obecnością przedmiotów w przestrzeni i czasie lub też ich obecnością w świadomości a intersubiektywnością jako relacją między podmiotami obdarzonymi samoświadomością. Obecność człowieka jako złożonej całości - a w szczególności Boga i innych bytów duchowych - leży niejako poza granicami tego, co widzialne, naoczne, choć wspiera się zasadniczo na tym, co dostępne postrzeganiu zmysłowemu ${ }^{11}$. Na fakt ten zwraca uwagę Gabriel Marcel, wyraźnie podkreślając, iż obecność dotycząca podmiotu, tj. osoby, jest czymś nieproblematyzowanym, nienadającym się do ścisłej obiektywizacji, zupełnie inaczej niż w przypadku przedmiotów, które zawsze są czymś określonym, policzalnym ${ }^{12}$. Obecność przedmiotów uchwytywana jest przez świadomość i określana mianem poznania. Obecność osoby dla osoby ufundowana jest na wydarzeniu spotkania:

9 Por A. Harnas, Czas i obecność, Kraków 2005, s. 163.

10 A. Gielarowski, Tajemnica obecności. Bycie i intersubiektywność w filozofii Gabriela Marcela, Kraków 2003, s. 258.

11 Por. A. Gielarowski, Tajemnica obecności..., dz. cyt., s. 265.

12 Por. A. Gielarowski, Tajemnica obecności..., dz. cyt., s. 261. 
Spotkanie może mieć różne powody, które nie zawsze są ważne; ważne jest przekształcenie spotkania w obecność, mającą charakter pewnej wspólnoty, czyniącą z dwóch osobnych podmiotów, z dwóch „ja”, coś trzeciego, wspólnego im, jakąś postać „my”. To communio personarum filozofowie klasyczni nazywali zazwyczaj przyjaźnią $[\ldots]^{13}$.

Aby uzupełnić i nieco sproblematyzować powyższą kwestię, warto przytoczyć opinie Józefa Tischnera oraz Artura Andrzejuka. Tischner zwraca uwagę, iż człowiek musi być już jakoś uprzednio obecny przed spotkaniem, obecny dla samego siebie, samo-siebie-posiadający (egotyczność), choć pełne odsłonięcie owej samo-obecności dokonuje się dopiero w wydarzeniu spotkania ${ }^{14}$. Z kolei zdaniem Andrzejuka należy odróżnić kategorię spotkania od samej obecności. Spotkanie w potocznym rozumieniu jest czymś, co ma charakter wydarzeniowy, intensywny, lecz zarazem krótkotrwały. Obecność, przeciwnie, kojarzona jest na ogół z pewnym stanem, czymś bardziej trwałym i stabilnym. Co więcej, zdaniem wspomnianego filozofa, kategoria obecności jest bardziej adekwatna do opisu autentycznej relacji międzyosobowej, gdyż w przeciwieństwie do kategorii spotkania wyzbyta jest funkcji obiektywizacji, tj. uprzedmiotowiania - w jakimś sensie bowiem spotykamy również przedmioty świata materialnego.

\section{OBECNOŚĆ BOGA}

Kategoria obecności posiada szczególne znaczenie w horyzoncie egzystencji religijnej. Poniekąd uzasadnione wydaje się twierdzenie, iż bez doświadczenia obecności Boga nie może być mowy o religii, przynajmniej w jej teistycznym rozumieniu. Religia zaczyna się bowiem w momencie

${ }^{13}$ A. Andrzejuk, Metafizyka obecności. Wstęp do teorii relacji osobowych, WarSzawa 2012, s. 15 .

${ }^{14}$ Por. Ł. Ćwiertnia, Kategoria obecności w filozofii Józefa Tischnera, [w:] Metafizyka obecności..., dz. cyt., s. 153-156. 
częściowego odsłonięcia realności, tj. obecności Boga, co z kolei ujmowane jest w języku religii bogatym znaczeniowo terminem objawienie (revelatio). Jak już wspomniano, obecność, w kontekście intersubiektywności, jest byciem dla, relacją, więzią. Te kategorie z kolei doskonale nadają się do opisu rzeczywistości życia religijnego, przede wszystkim wiary religijnej. Religia jako taka - zauważa Marek Szulakiewicz - domaga się swoistej metafizyki obecności, której jednak nie należy utożsamiać z ontoteologią, czyli dowodzeniem istnienia Boga, lub też z próbą dyskursywnego wyrażenia Jego Istoty. Metafizyka obecności polegałaby raczej na przyświadczeniu, uznaniu faktu istnienia Boga, przekonaniu, wierze, że w istocie Bóg jest taki, jakim Go poznajemy i opisujemy w oparciu o objawienie i na drodze spekulacji. Akt ten jest czymś absolutnie podstawowym dla życia religijnego. Marek Szulakiewicz pisze:

Tematyzacja Boga w przestrzennie zorganizowanym doświadczeniu religijnym, w którym myśli się w kategoriach widzenia i domaga się naoczności, nie może być oddzielona od metafizyki obecności. W doświadczeniu takim wymaga się koncentracji na „być”, istnieć, zaś religia (człowiek religijny) odkrywa Boga zawsze wokół pytania „Czy Bóg jest?”, „Czy Bóg istnieje?". Jest to swoisty metafizyczny typ religijności, w którym droga do Boga wymaga zawsze przejścia przez jakieś stanowisko metafizyczne, którego nieodpartym fundamentem jest uznanie, że „Bóg jest” oraz „jest takim, jakim Go opisujemy”. I nie można być religijnym bez uznania tej podstawy, fundamentu. Jeśli człowiek go utraci, to tym samym zamyka się przed nim cały obszar doświadczenia religijnego. Wynika on z bezpośredniej relacji egzystencjalnej i pytania „Gdzie jesteś?” [... $]^{15}$.

Zdaniem autora powyższego fragmentu religia zawsze rozpoczyna się od jakiegoś ,jest” Boga, od Jego zapośredniczonej - np. poprzez sacrum - lub „bezpośredniej” obecności (epifanie), zaś poszukiwanie tej obecności jest naturalną i usprawiedliwioną potrzebą homo religisous. To jednak nieuchronnie wiąże się z niebezpieczeństwem „przy-

${ }^{15}$ M. Szulakiewicz, Religia i czas, Toruń 2008, s. 171. 
właszczenia Boga”, tzn. ze sprowadzeniem go do określonego wymiaru tu i teraz, często też do egoistycznego traktowania Boga jako środka do realizacji własnych celów lub też z niebezpieczeństwem idolatrii ${ }^{16}$. Na gruncie teistycznym eksplikuje się przede wszystkim fakt, iż obecność Boga w świecie ma wymiar totalny, jest zatem wszechobecnością. Richard Swinburne pisze: „Twierdzenie, że Bóg bezpośrednio kontroluje wszystkie rzeczy i wie o wszystkich rzeczach bez informacji docierających do Niego przez jakiś łańcuch przyczynowy, np. bez promieni światła biegnących z pewnej odległości i potrzebnych do pobudzenia Jego oczu, było często wyrażane w postaci doktryny o wszechobecności Boga"17. Rozumienie wszechobecności Boga musi z jednej strony w sposób adekwatny wyrażać immanencję Boga, z drugiej czynić zadość koncepcji bytu transcendentnego, tj. przekraczającego skończoność stworzonego świata. Klasyczną wykładnię koncepcji obecności Boga w świecie znajdujemy w Summie teologicznej Tomasza z Akwinu, który pisze: „Bóg jest zatem we wszystkich rzeczach przez swoją moc, ponieważ wszystko podlega Jego potędze. Jest we wszystkim przez obecność dlatego, że wszystko jest odkryte i jawne Jego oczom. Jest też we wszystkim przez istotę, ponieważ jest obecny we wszystkim jako przyczyna istnienia [...]" ${ }^{18}$. Jest to metafizyczna koncepcja obecności Istoty Boskiej. Tymczasem z punktu widzenia świadomości homo religiosus bardziej znaczący wydaje się jednak ten typ obecności Boga, który można wyrazić za pomocą przyimka „dla”. Obecność Boga jest obecnością „dla” człowieka. Owo „dla” wskazuje, po pierwsze, na istotny fakt, iż Bóg staje się obecny właśnie dla świadomości człowieka - w tym też sensie człowiek jest niejako właściwym światem manifestacji Boskiej obecności. Po drugie, słówko „dla” wskazuje na fakt obdarowania. Obecność Boga, jawna, tj. rozpoznana, odkryta, uświadomiona, jest dla jestestwa najwyższą, najcenniejszą postacią daru, odnoszącą się do czło-

${ }^{16}$ Por. M. Szulakiewicz, Religia i czas, dz. cyt., s. 172-173.

17 R. Swinburne, Spójność teizmu, tłum. i wstęp T. Szubka, Kraków 1995, S. 153.

18 Tomasz z Akwinu, Traktat o Bogu. Summa teologii, tłum. i koment. G. Kurylewicz, Z. Nerczuk, M. Olszewski, Kraków 1999, kwestie 1-26, s. 105. 
wieka jako całości. Obecność Boga „dla” człowieka to obecność Boga Żywego, obecność Boga wiary, Boga Abrahama, Izaaka i Jakuba. „Bóg wiary obecny jest jakoś dla całego człowieka, nie tylko dla rozumu, lecz najgłębiej osobiście dla tego oto konkretnego «ja», także więc dla jego uczucia i woli (by trzymać się klasycznego trójpodziału «władz» człowieka)"19. Obecność Boga dla świadomości religijnej wyrażana jest często terminem bliskość. Owa bliskość Boga, mająca charakter egzystencjalny, jest ufundowana na fakcie ontologicznym, na istotowej obecności Boga w człowieku:

Drugi sposób bycia Boga per praesentiam, ów będący „obecnością istotową", ujawnia się jedynie w stworzeniu rozumnym, o ile ono aktualnie poznaje i miłuje Boga. Tomasz powie, że taka bliskość Boga jest właściwa działaniu duszy, jej poznaniu i jej pożądaniu (chceniu), „zgodnie z tym, że poznane [przedmiot poznania] jest w poznającym, i pożądane [rzecz upragniona] w pożądającym" (secundum quod cognitum est in cognoscente, et desideratum in desiderante). Jest to więc obecność Boga jako „przedmiotu działania będącego w działającym” ${ }^{20}$.

Oto kilka sposobów manifestacji obecności Boga. Jest to obecność poprzez: słowo, opatrzność, stworzenie, mistykę. Obecność Boga poprzez słowo była częstym tematem rozważań teologicznych, np. w koncepcji Boskiego Logosu. Paul Tillich podkreśla wydarzeniowy charakter słowa wypowiedzianego przez Boga. Bóg wypowiadając słowa objawienia, wypowiada samego siebie, staje się w rzeczywisty, choć niewątpliwie tajemniczy sposób obecny poprzez wypowiedziane przez siebie słowo:

W religii biblijnej Bóg mówi do człowieka. „Słowo” jest, ściśle biorąc, wypowiadanym dźwiękiem lub pisanym znakiem; oba zawierają

${ }^{19}$ K. Tarnowski, Człowiek i transcendencja, wstęp J. Tischner, Kraków 2007, s. 139-140.

${ }^{20}$ M. Mróz, Bliskość i nieskończoność. Kilka uwag na temat obecności Boga w świecie na kanwie "filozofii negatywnej” św. Tomasza z Akwinu odczytanej dzisiaj, „Pedagogia Christiana" 32 (2013) nr 2, s. 44. 
w sobie pewne znaczenie, z którym są tradycyjnie związane. Jest jednak rzeczą jasną, że Bóg Biblii nie mówi ani nie słucha w ten właśnie sposób. Jego „Słowo” jest wydarzeniem, które za sprawą Jego Ducha dokonuje się w ludzkim duchu. „Słowo” Boga jest Jego stwórczym samoobjawieniem, nie zaś rozmową dwóch istot. Dlatego „Słowo” to jest elementem samego Boga; jest to w danym momencie uprzedmiotawiający siebie samego Bóg. Jest ono wyrazem żywego Boga [...]. Jest ontologicznie w swoich konsekwencjach, chociaż stanowi autentycznie religijny symbol ${ }^{21}$.

Kolejny sposób, w jaki człowiek religijny odkrywa obecność Boga, związany jest z pojęciem opatrzności (łac. providentia): „Jest ono ściśle związane z obecnością w świecie boskiego Logosu - który z jednej strony uosabia zamiar Bożej mądrości wobec świata, z drugiej zaś boską pankosmiczną władzę"22. Należy podkreślić, że Opatrzność ma charakter dynamiczny, tzn. dokonuje się poprzez konkretne wydarzenie, które z kolei świadomość religijna w sposób spontaniczny przypisuje Bogu, szczególną zaś rolę nadaje cudom, czyli nadzwyczajnym interwencjom Boga w świecie. Dla homo religisous cud jest wyraźnym znakiem obecności Boga. Jest to obecność „dla” w sensie ścisłym, chodzi w niej bowiem o afirmację dobra konkretnego człowieka. Istotnym sposobem, w jaki świadomość religijna odkrywa Bożą obecność, jest również kontemplacja świata jako Boskiego dzieła stworzenia:

Obecność Boga wyrażała się przede wszystkim poprzez Jego dzieło, jakim jest racjonalny i uporządkowany świat oraz człowiek, którego istota - rozumność - stanowi ontologiczną więź łączącą go z Bogiem. Racjonalność była zatem nicią, po której krocząc, człowiek przybliżał się do rozumienia nie tylko natury świata, lecz także natury samego

${ }^{21}$ P. Tillich, Pytanie o nieuwarunkowane. Pisma z filozofii religii, tłum. J. Zychowicz, Kraków 1994, s. 127. Por. M. Szulakiewicz, Religia..., dz. cyt., s. 215.

${ }^{22}$ T. Węcławski, Abba wobec Boga Ojca, Kraków 1999, s. 44. 
Boga. [...] Więzi niegdyś łączące nas z Bogiem zostały zerwane. W takim świecie coraz trudniej dostrzegać obecność Boga. Źródłowe drogi do Boga stają się coraz bardziej niedostępne, obcujemy jedynie ze śladami Boga ${ }^{23}$.

Należy wreszcie wymienić płaszczyznę doświadczania obecności Boga, interesującą nas w tej pracy najbardziej: jest nią ściśle duchowy wymiar egzystencji człowieka. Szczytowym, a co za tym idzie, trudnym do wyrażenia momentem tego odsłonięcia obecności jest doświadczenie mistyczne jako wydarzenie dokonujące się:

[...] nagle w sposób niezaplanowany, nie wypracowany przez nas, bez żadnej naszej zasługi, niezależnie od tego, cośmy zrobili, pojawia się w nas Bóg w taki sposób, że mamy pewność intelektualną Jego obecności. I to przeżycie nazywa się doświadczeniem mistycznym. Obecność, która jest potwierdzeniem tego wszystkiego, czego dowiedziałem się $\mathrm{z}$ wiary, nagła, niczym nie wywołana, zaskakująca $[\ldots]^{24}$.

\section{DEUS ABSCONDITUS - BÓG UKRYTY}

Kategoria obecności nabiera szczególnego znaczenia w zestawieniu z kategorią nieobecności. Aleksander Bobko nawiązując do Platona pisze:

[...] otaczająca człowieka rzeczywistość niby jest obecna, ale być może jest tylko cieniem; to, co dla człowieka naprawdę interesujące, pozostaje w ukryciu, ale nieobecność owej upragnionej, prawdziwej rzeczywistości ma także swoją specyficzną wymowę. Dramat człowieka rozgrywa się

\footnotetext{
${ }^{23}$ D. Kozłowska, Metafizyka obecności a metafizyka śladu, [w:] Metafizyka obecności..., dz. cyt., s. 117-118.

${ }^{24}$ M. Gogacz, Filozoficzne aspekty mistyki. Materiaty do filozofii mistyki, Warszawa 1985, S. 100.
} 
zatem pomiędzy obecnością i jej cieniem, a nasze życie upływa na poszukiwaniu tego, co powinno być trwale obecne ${ }^{25}$.

Bóg w tradycji judeochrześcijańskiej jest nie tylko Bogiem obecnym, tj. manifestującym tu oto swój byt dla świadomości religijnej. Jest również Deus absconditus, Bogiem ukrytym, ponad światem - a właściwe poza-światem - bytem transcendentnym. Świat jest swoistą zasłoną skrywającą obecność Boga. Skrytość Boga często utożsamiana jest z Jego nieobecnością w świecie (deizm), a niekiedy z samym nieistnieniem (ateizm). Max Scheler pisze: „[...] idea ukrywającego siebie samego i milczącego Boga, który kryje w milczeniu nawet siebie i swoje istnienie, jawi nam się jako to, czym ona [faktycznie] jest, mianowicie jako idea okropnego upiora (Gespenst), który nie może mieć istnienia, bo nie może też istnieć coś sprzecznego" ${ }^{26}$. Tymczasem doświadczenie skrytości Boga jest niejako integralnym składnikiem wiary religijnej, niezależnie od epoki, w której realizuje się dane jestestwo religijne: „Doświadczenie Boga oznacza często dla współczesnego człowieka przeżywanie «Boga tajemniczego», «Boga ponad wszelkie wyobrażenie». Tak doświadczył Boga wielki chrześcijański teolog z czwartego stulecia, Grzegorz z Nyssy"27. Można zaryzykować twierdzenie, iż religia jest tym, co człowiek czyni z nieobecnością - w każdym razie pozorną nieobecnością - Boga, a już na pewno z faktyczną Jego skrytością. Gdyby Bóg nie był absconditus, tj. Bogiem ukrytym, częściowo zasłoniętym, istniejącym w pewnym oddaleniu od człowieka i świata, religia jako poszukiwanie Boga straciłaby dla siebie dostateczną rację. Jak zauważa Mirosław Mróz, myśl o nieprzezwyciężalności dialektyki obecności i skrytości Boga, idea komplementarności tych dwóch ontologicznych faktów zawarta jest też w fundamentalnej dla zachodniej myśli religijnej teologii Tomasza z Akwinu:

${ }^{25}$ A. Bobko, Wprowadzenie. Rozważania wokót pojęcia obecności, [w:] Metafizyka obecności..., dz. cyt., s. 6.

${ }^{26}$ M. Scheler, Problemy religii, tłum. A. Węgrzecki, Kraków 1995, s. 336.

27 L. Boros, Doświadczenie Boga, tłum. B. Tarnas, Warszawa 1983, s. 116. 
Czy łącząc bliskość Boga i Jego oddalenie, nieskończoność ze skończonością, możemy odkryć w myśli Akwinaty coś ciekawego? Wydaje się bowiem, że zagadnienie poznawalności i bliskości Boga jest raczej problematyką właściwą nowoczesności, gdzie rozumie się ową „bliskość” jako relację, jako wzajemne zbliżenie. Jest jednak także drugie oblicze współczesnej filozofii religii, gdzie dominuje tendencja prezentacji Boga jako nieznanego, jako niewypowiedzianego, który choć jest blisko, pozostaje dla człowieka ciągle tajemnicą. Z jednej strony „oddalenie” i „zakrycie”, z drugiej Jego „ukazanie się” i „objawienie”. [...] Tomasz w swojej prezentacji bycia nieskończonego Boga w świecie stosuje ową komplementarność „bliskości” i „oddalenia”, zachowanej tajemnicy i naoczności. Akwinata, operując bowiem tradycyjnym pojęciem bytu, nie zapomina o tym, że człowiek nigdy nie zdoła na tyle zbliżyć się do Boga, aby Go ująć i posiąść dla siebie ${ }^{28}$.

Louis Dupré wskazuje na ścisły związek obecności z kategorią objawienia. Czytamy: „W objawieniu Bóg musi w jakiś sposób komunikować swą własną rzeczywistość. Jest to więcej niż przesłanie o Jego rzeczywistości, gdyż istotną «treścią» jest sam Bóg”"29. Nie sposób się z tym nie zgodzić. Paradoksalnie jednak objawienie ma również osobliwy związek nie tylko z obecnością Boga, ale i również z Jego skrytością. Skrytość Boga, Jego tajemniczość, nieoczywistość, jest zawarta już w samym wydarzeniu objawienia. Objawienie bowiem - jak zauważają teolodzy - nigdy nie jest zupełnym wypowiedzeniem Tego, który ze swej istoty jest niewysłowiony. Objawienie jako odsłonięcie (revelatio) nie jest odarciem Boga z Jego Tajemnicy, całkowitym pojęciem natury Boskiej przez skończony ludzki umysł. W pojęciu skrytości Boga zawiera się zatem paradoks, nie mniejszy niż ten, który można dostrzec w pojęciu śmierci Boga. Oto Jestestwo, któremu należy przypisać ex definitione istnienie - realność, wobec której wszystko zdaje się być pozorne i ledwo rzeczywiste - ukrywa się:

${ }^{28}$ M. Mróz, Bliskość i nieskończoność..., dz. cyt., s. 28-29.

${ }^{29}$ L. Dupré, Inny wymiar, tłum. S. Lewandowska-Głuszyńska, Kraków 2003, s. 249. 
[...] objawienie ostatecznie ujawnia nieprzenikalną ciemność boskiej tajemnicy Abraham Heschel zwrócił uwagę na znaczący fakt, że być może najstarszy przykład teologii negatywnej pojawia się w opisie boskiego objawienia. Zawarta w Pierwszej Księdze Królewskiej (19, 11-12) opowieść o objawieniu się Boga Eliaszowi opisuje Pana jako będącego obecnym nie w wichrze, trzęsieniu ziemi czy ogniu, lecz w „głosie ciszy", który nastąpił po ogniu. [...] Bóg taki, jaki jest w sobie, pozostaje Deus absconditus, nawet jeśli objawia siebie, gdyż aby objawić siebie prawdziwie, musi On objawić się jako transcendentny, czyli jako ostatecznie będący poza zrozumieniem ${ }^{30}$.

Jak już powiedziano, skrytość Boga częstokroć mylona jest z Jego nieobecnością. Ta nuta sceptycyzmu zdaje się pobrzmiewać w książce Idea Boga po Auschwitz Hansa Jonasa, dla którego Bóg jest - a przynajmniej był przez pewien czas - Bogiem nieobecnym $<t u$ oto $>$, przy swoim dziele, przy swoim stworzeniu. Oto bowiem, zdaniem Jonasa, doświadczenie totalitaryzmu postawiło pod znakiem zapytania naszą dotychczasową „wiedzę” o Bogu. Czy w istocie Bóg jest doskonały, wszechmocny i dobry? Pojawia się zatem klasyczna teodycealna kwestia: Dlaczego Bóg nie wysłuchał modlitwy w obliczu zła? Żydowski filozof daje odpowiedź: „Natomiast Bóg milczał. Teraz powiem: nie ingerował nie dlatego, że nie chciał, lecz dlatego, że nie mógł. [...] proponuję ideę Boga, który na pewien czas - na czas postępującego kosmicznego procesu - zrzekł się wszelkiej władzy ingerowania w fizyczny przebieg spraw świata [...]"31. Skrytość Boga wyrażana jest często terminem milczenie Boga. Świat - zwłaszcza dla człowieka współczesnego - zdaje się być rzeczywistością, która przemawia w sposób apodyktyczny, bezkompromisowy, hałaśliwy, nie dopuszczając innych głosów, innej rzeczywistości. Stąd odmowa istnienia Bogu, którego głos jest słaby, niesłyszalny, który nie przemawia już

\footnotetext{
${ }^{30}$ L. Dupré, Inny wymiar..., dz. cyt., s. 251.

${ }^{31}$ H. Jonas, Idea Boga po Auschwitz, tłum. G. Sowinski, Kraków 2003, s. 43.
} 
jak niegdyś, który milczy, być może nie istnieje albo jest obojętny na los człowieka. Milczenie nie jest jednak tym samym co nieobecność:

Czym innym jest jednak „Bóg, który milczy”. Świat milczącego Boga łatwo pomylić z ciszą nicości. Łatwo też pomylić „Boże milczenie” z nieistnieniem Boga. [...] To wielce kłopotliwe milczenie często wytrąca człowieka z równowagi. Skoro Bóg nie tylko nie staje się rezultatem dowodu, ale też „milczy”, to pozostaje jedyny wniosek - odmowa uznania istnienia $\mathrm{Boga}^{32}$.

Nie jest to jedyny możliwy wniosek. Bowiem świadomość religijna milczeniu Boga może przypisać jakąś istotną rację, przede wszystkim zaś nie należy zapominać o prostym zgoła fakcie: „To znaczy, «niemówienie» nie jest wcale milczeniem. Bóg milczy, co wcale nie znaczy «nie mówi», «ani nie ma nic do powiedzenia». Odwrotnie, milczenie to jest niezwykle wymowne, stając się naszą drogą do prawdy"33. Jakie są zatem powody, dla których Bóg nie przemawia do człowieka głosem potężnym i donośnym? Najważniejszym z nich jest - jak podkreślają teolodzy - kondycja człowieka, który w obecnej naturze nie byłby w stanie zrozumieć Boskich słów, ale i więcej, nie byłby w stanie znieść nadmiaru rzeczywistości odsłaniającego się Boga, niezależnie od tego, czy byłoby to odsłonięcie przez „mowę”, czy poprzez widzenie "niejako twarzą w Twarz”. Inaczej mówiąc, milczenie czy skrytość Boga jest doskonałą metaforą Jego absolutności, świętości:

Milczeniu Boga, podobnie jak milczenie człowieka w spotkaniu z Bogiem i Jego blaskiem, zagraża to, że zostanie zrozumiane jako niemoc Boga i przemilczenie Boga przez człowieka. Lecz spotkanie w milczeniu z jednej strony chroni skończoną siłę rozumienia człowieka, zapobiegając w ten sposób utonięciu człowieka na sposób kropli znikającej w morzu nieskończoności. Z drugiej strony umożliwia ono pojęcie absolutności

${ }^{32}$ M. Szulakiewicz, Religia..., dz. cyt., s. 218.

${ }^{33}$ Tamże, s. 221. 
Boga, którego istnienie i relacja do skończoności człowieka są niezgłębione. Człowiek stojący wobec tajemnicy Jego obecności i świata w ogóle widzi więc, że dialektyka mówienia i milczenia jest konstytutywną cechą filozoficznego myślenia o Bogu ${ }^{34}$.

Z punktu widzenia człowieka religijnego skrytość Boga zdaje się być korzystna z jeszcze jednego powodu. Oto człowiek religijny nie poszukuje widzenia czegoś, czy raczej Kogoś, kto sam ze swej istoty jest niewidzialny, jest poza kategorią naoczności. Obecność nie zawsze oznacza naoczność, zawsze towarzyszy jej tajemnica, jakaś epistemologiczna nieprzenikalność, która zarazem chroni ją przed obiektywizacją: „Obecność, tak jak tajemnica, nie może być poznana jasno i wyraźnie, gdyż należy do sfery metaproblematycznej. Dlatego, jako nienależąca do świata przedmiotów, obecność ani nie może być posiadana, ani nie daje się scharakteryzować"35. Bóg skrywa swoje istnienie za zasłoną bytów skończonych, ale bynajmniej nie skrywa całkowicie swojej obecności. Homo religiosus poszukuje tej obecności bardziej niż pewności wiedzy na temat istoty i istnienia Boga. To balansowanie między biegunami obecności i skrytością Boga należy do specyfiki egzystencji religijnej:

Wiedza, która jest niewiedzą; bliskość, która się oddala, obecność, która się uchyla [...] czujemy, że to musi tak właśnie być, gdyż On jest Bogiem. Jakiś przymus w tym wszystkim; delikatna i potężna siła, z jaką narzu-

${ }^{34}$ N. Fischer, Człowiek w poszukiwaniu Boga. Zagadnienia filozoficzne (Podręczniki Teologii Katolickiej, 2), tłum. J. Świerkosz, Poznań 2004, s. 35. Milczenie w ścisłym sensie oznacza też niepoznawalność. Absolut jako Wielkie Milczenie jest nieosiągalny na drodze intelektualnej ani na drodze słowa. Jest On Niewysłowiony, Niewyrażalny, Niewytłumaczalny, poza zasięgiem słowa, poza zdaniem, poza językiem; jest wcześniejszy niż słowo. Dostępny jest jako Milczenie i poprzez milczenie istoty ludzkiej, która jest w Nim zanurzona: „Deum tacendo cognoscimus”. Również i kult powinniśmy oddawać Bogu przez milczenie. Toteż filozofia musi się posłużyć pojęciami „milczeniowymi”. O Bogu mówi „metafizyka milczenia”: C. S . Bartnik, Dotknąć Boga Żywego. Różne szkice teologiczne (Dzieła zebrane, 35), Lublin 2004, s. 34.

${ }^{35}$ A. Gielarowski, Tajemnica obecności..., dz. cyt., s. 282-283. 
ca się On uczuciu - oto jest Żywy Bóg. Napiera na nas, odsłania się... przenika wszystko... jest prawdziwą Rzeczywistością - i właśnie dlatego, że tym wszystkim jest, jest daleki. Dlaczego? Gdyż przesłania Go nam nasza skończoność. To my sami jesteśmy powodem tej chwiejności poznania, tego „i tak, i nie”, to my zasłaniamy Objawionego. [...] Nasze oczy nie tylko nie wytrzymują nieskończonej intensywności Jego Bytu, ale ponadto opanowane są przez złą wolę, brak koncentracji, patrzą nie tam, gdzie trzeba ${ }^{36}$.

Bóg nie zawsze pozostaje w ukryciu, odsłania się w kluczowych momentach, w granicach naszej skończoności, lecz przede wszystkim w horyzoncie własnej woli, stąd też poczucie bliskości i oddalenia Boga, nieuchronne, a zarazem dające możliwość wiary religijnej, zawierającej oprócz tego, co pewne, momenty częściowego zawieszenia, dramatyczności, niepewności, nierozstrzygalności, co z punktu widzenia rozwoju człowieka jako takiego ma znaczenie fundamentalne. Egzystencja na poziomie świadomości dziecka potrzebuje obrazów, dojrzała egzystencja wzrasta dzięki wierze, która nie opiera się nie na widzeniu, lecz na tajemniczym, a zarazem rzeczywistym poczuciu obecności Tego, co Niewystowione.

\section{CAPAX DEI}

Słuszne skądinąd wydaje się założenie, iż musi istnieć jakiś warunek umożliwiający uchwycenie owej obecności Boga, zwłaszcza obecności jako bycia „dla”. Warunek ten w antropologii chrześcijańskiej określany jest jako capax Dei, otwartość czy też ukierunkowanie na Boga. Capax Dei jako powszechny i niezbywalny element kondycji ludzkiej został chyba najsubtelniej wyrażony w słynnych słowach Augustyna z Hippony, który pisze: „Stworzyłeś nas bowiem jako skierowanych ku

${ }^{36}$ R. Guardini, Bóg daleki, Bóg bliski, tłum. J. Koźbiał, Poznań 1991, s. 83. 
Tobie. I niespokojne jest serce nasze, dopóki w Tobie nie spocznie”37. Na czym owo skierowanie miałoby dokładnie polegać?

Przede wszystkim na zdolności do szukania Boga, poznawania Go i miłowania, ostatecznie zaś na powołaniu, aby coraz bardziej miłując Go i poznając, podążać za Nim do miejsca, które mistycy określają jako trzecie niebo, obłok niewiedzy lub królewska komnata. Człowiek jest otwarty na Boga po to, by móc przylgnąć do Niego i ujrzeć Jego oblicze. Według Bernarda, wielkość i wyjątkowość człowieka wyraża się w dużo większym stopniu właśnie w tym mistycznym powołaniu niż w czymkolwiek innym. Jako capax Dei każdy człowiek jest w głębi swej natury wezwany, by zobaczyć to, co ujrzał Mojżesz, wchodząc w obłok skrywający Boga, usłyszeć to, czego dowiedział się św. Paweł porwany do trzeciego nieba, i doświadczyć tego, co przeżył Bernard, wchodząc do królewskiej komnaty swego Oblubieńca. Tylko odpowiadając na to powołanie możemy spełnić najgłębsze pragnienie naszej natury, w pełni być sobą, $\mathrm{w}$ pełni realizować nasze odwieczne przeznaczenie ${ }^{38}$.

Prymat objawienia wobec odpowiedzi człowieka w wierze i religii nie podlega wątpliwości - przynajmniej dla człowieka wierzącego. To Bóg uczynił niejako pierwszy krok w stronę ludzkości, mówiąc co nieco o sobie. Niemniej po stronie człowieka również konieczne jest pewne minimum zdolności do przyjęcia Boskiego gestu odsłonięcia poprzez słowo i zapośredniczone w nim wydarzenie spotkania. Eric Lionel Mascall pisze tak oto:

[...] kiedy Bóg się nam objawia, udziela nam wraz z objawieniem mocy do Jego rozpoznania i zrozumienia, to musielibyśmy znowu stanąć na stanowisku, iż nawet w takim przypadku umysł ludzki musi mieć naturalną zdolność do otrzymania tego rodzaju mocy. Tak czy inaczej to,

37 Augustyn z Hippony, Wyznania, tłum. Z. Kubiak, Kraków 2002, s. 25.

${ }^{38}$ R. Tichy, Mistyczna historia człowieka według Bernarda Clairvaux, Poznań 2011, s. 11. 
co skończone, musi być capax infiniti. O ile w naturze ludzkiej nie tkwi jakiś Anknüpfungspunkt, choćby najmniejszy, między Bogiem a człowiekiem, o ile człowiek nie posiada z natury pewnej potentia oboedientialis, jakiejś wrażliwości, choćby najsłabszej, na to, co nadprzyrodzone, Bóg nie będzie zdolny do porozumienia się z człowiekiem, ponieważ nawet gdyby Bóg przemówił, człowiek nie potrafiłby Go usłyszeć ${ }^{39}$.

Otwartość jako taka nie jest tylko naddatkiem, bez którego człowiek mógłby sobie doskonale poradzić w świecie. Bez niej człowiek jako istota skończona, krucha w swym istnieniu, egzystencjalnie zależna od innych bytów, a ostatecznie zależna od Bytu Najwyższego - i to właściwie we wszystkim - nie byłby w stanie przeżyć chwili, a co dopiero mówić o zmaganiu człowieka z własną historią, długą, pełną trudów, obfitującą w momenty krytyczne. Józef Krasiński pisze o owej konieczności otwartości bytu ludzkiego tak oto:

[...] pierwotnym i zasadniczym przeżyciem człowieka jest doświadczenie własnej egzystencjalnej niewystarczalności i niepełności istnienia. Język filozoficzny określa to doświadczeniem przygodności bytowej. Człowiek wie i odczuwa nieustannie, że nie jest panem swojej egzystencji, że ona nie zależy całkowicie od niego. Ma poczucie uczestniczenia $\mathrm{w}$ istnieniu, ale nie bycia istnieniem. [...] To doświadczenie kruchości, własnej niewystarczalności, przygodności istnienia prowadzi człowieka w kierunku przekroczenia tych ograniczeń i odnalezienia dobra, mocy i innych wartości, które nadałyby sens jego egzystencji niepełnej, kruchej, podlegającej ustawicznym zmianom. Człowiek dąży do szczęścia pełnego, niezmąconego, pragnie, by jego osobowe życie było dopełnione przez mocne, transcendentne Ty. Ta otwartość człowieka na Byt Transcendentny to istotna podstawa religii i religijności ${ }^{40}$.

${ }^{39}$ E. L. Mascall, Otwartość bytu. Teologia naturalna dzisiaj, tłum. S. Zalewski, Warszawa 1988, s. 177.

${ }^{40} \mathrm{~J}$. Krasiński, Homo religiosus. Podmiotowo-personalistyczne ujęcie fenomenu religijnego, Sandomierz 2002, s. 100-101. 
Owej niewystarczalności bytu ludzkiego - jak również owej niedostateczności, kruchości wszystkiego, co może stanowić ewentualne oparcie dla egzystencji - przypisywany jest głęboki zamysł samego Boga. Niewystarczalność człowieka i świata, który go otacza, odsyła go ku Bytowi, który jako jedyny nie tylko jest w swym istnieniu autarkiczny, ale który również z tej pełni, doskonałości dobra może udzielić coś tej egzystencji, temu jestestwu, które w akcie wiary przenikniętym pokorą, tj. prawdą o własnej kondycji, przybliża się ku Niemu jako Najwyższemu Dobru. Referując myśl Nicolasa Malebrancha, Leszek Łysień pisze tak oto:

Fundamentalne skłonności stworzeń muszą odpowiadać woli i intencjom Stwórcy. W związku z tym Bóg zaszczepił w stworzeniach duchowych zasadniczą skłonność ku sobie samemu. Dlatego żadne dobro skończone nie jest w stanie zaspokoić pragnienia stworzenia, które jest skierowane ku Dobru samemu ${ }^{41}$.

\section{CZEOWIEK SZUKAJĄCY BOGA - QUAERERE DEUM}

Capax Dei jako otwartość bytu ludzkiego na Boga to element pasywny kondycji człowieka, pewna potencjalność, która domaga się jednak aktualizacji poprzez akt religijny, obojętnie czy jest to akt wiary, nadziei, miłości, modlitwy itd. Wszystkie owe akty są zasadniczo wyrazem tego, co w antropologii chrześcijańskiej nazywano quaerere Deum, tj. poszukiwaniem Boga:

Poszukiwanie Boga (quaerere Deum) towarzyszy człowiekowi od zawsze. Tradycja chrześcijańska, podobnie jak starożytne wierzenia i filozofia pogańska, zagadnienie quaerere Deum uczyniła istotnym elementem swojego zainteresowania już od czasów pierwszych Ojców Kościoła.

${ }^{41}$ L. Łysień, Bóg, rozum, wiara. Problematyka filozofii Boga od Talesa z Miletu do G. W. F. Hegla, Kraków 2003, s. 129. 
Dla pierwszych chrześcijan poszukiwanie Boga miało niekiedy sens dosłowny, gdyż poszukiwali oni znaków Jego nadejścia, poszukiwanie było wtedy czuwaniem pełnym niecierpliwości, pełnym dynamizmu, czasem świętych czynów, oczekiwaniem rychłej paruzji ${ }^{42}$.

Postacią, która w sposób doskonały - również poprzez własne życiowe doświadczenie - wyraziła ideał poszukiwania Boga, był niewątpliwie św. Augustyn. Poszukiwał on Boga przede wszystkim na podstawie auctoritas et ratio, wiary i rozumu; przestrzenią poszukiwania było jego własne wnętrze, dusza ludzka jako właściwy świat Boga:

Augustyn postrzega człowieka jako niespokojne serce, które nie jest w stanie osiągnąć utęsknionego pokoju ani w świecie, ani w sobie samym, lecz jedynie w Bogu: „Inquietum est cor nostrum, donec requiescat in te". Znalezienie samemu pokoju (quies ipse) przekracza skończone możliwości człowieka. Właściwe mu niepewność i słabość pozwalają jedynie na uznanie własnej niemocy i poszukiwanie prawdy, która budzi w człowieku nieskończoną tęsknotę i zachęca do szukania. Tak poszukiwanie, jak również odnajdywanie Boga należy rozumieć jako niewytłumaczalne wydarzenia. Bóg sam jest przedmiotem wiary jako Ten, który pobudza do szukania (tu excitas) i objawia siebie we wtargnięciu wieczności w czas ${ }^{43}$.

Poszukiwanie jest przede wszystkim aktem właściwym człowiekowi, to on jest tym, który niejako zagubit Boga. Poszukiwanie to jednak musiałoby być z góry skazane na niepowodzenie, gdyby nie wspaniałomyślny, z gruntu niełatwy do wytłumaczenia, w każdym razie ostatecznie niepojmowalny gest Boga uprzedzającego swym „wyjściem" ku człowiekowi cały jego wysiłek, by móc się do Niego zbliżyć. Znalezienie tej obecności wynika ostatecznie z woli Boga, który niejako pozwala się znaleźć:

\footnotetext{
${ }^{42}$ S. Jaśkiewicz, Św. Augustyn - poszukiwanie Boga, Katowice 2012, s. 16-18.

${ }^{43}$ N. Fischer, Człowiek w poszukiwaniu Boga..., dz. cyt., s. 412.
} 
[...] człowiek może co prawda „szukać” Bożego oblicza, ale nie może zmusić Boga, by mu ukazał swe oblicze. Mówiąc za prorokiem: człowiek może poszukiwanego Boga doświadczyć jako „bardzo ukrytego”, stąd swe poszukiwania oblicza Bożego może wypowiedzieć słowami prośby: „Szukam, o Panie, Twojego oblicza; swego oblicza nie zakrywaj przede mną" (Ps. 27 [26], 8-9)

Istnieje również doniosła tradycja myślenia o Bogu, w której Bóg nie tylko pozwala się znaleźć, lecz przede wszystkim On sam jest Tym, który w sposób właściwy sobie poszukuje człowieka:

W religii judeo-chrześcijańskiej inicjatorem objawienia się Boga względem człowieka i Jego zamiarów jest Bóg - Jahwe. On pierwszy wychodzi z inicjatywą odkupienia i objawienia. To nie człowiek szuka Boga, ale Bóg szuka człowieka. Bóg daje się poznać człowiekowi wychodząc niejako poza własne misterium. W religiach Wschodu bardzo często obserwujemy sytuację odwrotną, tam człowiek szuka Boga. Bóstwo objawia tylko swoją boskość ${ }^{45}$.

Zasadniczym instrumentem poszukiwania Boga jest ludzki umysł kontemplujący prawdę i byt (Augustyn), mówiąc inaczej, dostrzegający obecność Boga w świecie przyrody oraz w głębi wnętrza człowieka. Niemniej, jak słusznie zauważa Henry Duméry: „Dusza religijna zmierza ku Bogu poprzez wiarę, wcale zaś nie poprzez dialektykę. Nie znaczy to, że wierzący nie ucieka się do rozlicznych i subtelnych rozumowań, o ile tylko zada sobie trud przemyślenia swojej wiary. Ta jednakże bytuje na płaszczyźnie głębszej niż wszelka refleksja, można więc ją uznać za zjawisko innego porządku" ${ }^{46}$.

${ }^{44}$ R. Schaffler, O języku modlitwy, tłum. G. Sowinski, Kraków 2007, s. 101.

45 S. Głaz, Zagadnienie doświadczenia religijnego. Próba syntezy, Kraków 1995, s. $179-180$.

${ }^{46}$ H. Duméry, Problem Boga w filozofii religii. Krytyczny rozbiór kategorii Absolutu i schematu transcendencji, tłum. I. Kania, Kraków 1994, s. 40. 
Poszukiwanie Boga kończy się spotkaniem. Nie jest to spotkanie intelektualne, lecz osobowe, tj. totalne, angażujące całego człowieka: jego wolę, pamięć i umysł, a nawet ciało:

Spotkaniu intelektualnemu należy przeciwstawić osobowe, i z tego względu nadprzyrodzone, spotkanie człowieka z Bogiem. Jest ono nadprzyrodzone wtedy, gdy objawioną informację Boga uznajemy nie dla jej sensowności, odkrytej w rozumowaniu, lecz że objawił ją nieomylny i prawdomówny Bóg. Nasza decyzja opiera się wtedy nie na naszym rozumowaniu, lecz na autorytecie Boga, któremu ufamy i którego przyjmujemy w swej duszy, opierając na Nim naszą decyzję i argumentację. Takie uznanie prawd objawionych jest nadprzyrodzonym aktem wiary, aktualizującym osobową obecność w nas Boga. Ta osobowa obecność w nas Boga, podobnie jak każda relacja między osobami, wyraża się np. właśnie w obecności, rozmowie, przyjaźni. Obecność Boga w duszy osoby ludzkiej nazywa się w języku teologicznym łaską, rozmowa ze względu na swą specyfikę została nazwana w teologii modlitwą, a przyjaźń duszy ludzkiej z Bogiem ma wymiar miłości ${ }^{47}$.

\section{CATEGORY OF PRESENCE IN THE CONTEX OF RELIGION}

\section{SUMMARY}

The article is an analysis of the cathegory of Presence in the context of religion. The scope is to show the phenominon of presence as a fundamental cathegory in the aspect of religious existence. Article mentions definitions of presense known in both classical and modern philosophy. Especially interesting for the work is the concept of God's presence through: the word, the Providence, the world and the mystical experience. The matter of God's presence

${ }^{47}$ H. Duméry, Problem Boga..., dz. cyt., s. 142-143. 
is complemented by analisys of God's secrecy often discussed in the religious literature, especially in the theologhy of spirituality. The text is featuring reciprocal correlation, dialectics of both terms and the consequences for the spiritual life. There are mentioned antropological conditions of the posibility for religious relationship, especailly relationship in which the essence is the presence - that are: capax Dei (man's ability (and need) to relate to the Divine) and quaerere Deum (man's ability (and need) to seak for Divine).

KEYWORDS

Presence, secrecy, God present, God's hidden, encounter, revelation, God's closeness, homo religious, capax Dei, the persuit of God, the silence of God, Gabriel Marcel, Martin Heidegger, Abraham Joshua Heschel, Hans Jonas, Augustine of Hippo 